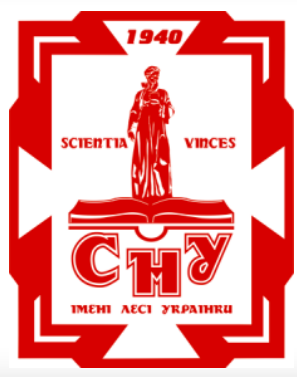

Науковий вісник Східноєвропейського національного університету імені Лесі Украӥнки

Розділ III. Фізіологія людини і тварин

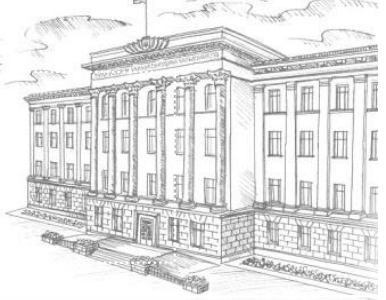

Серія: Біологічні науки, 2019, 4 (388)

УДК 612.172-055.25

DOI https://doi.org/10.29038/2617-4723-2019-388-4-115-124

\title{
Вплив інформаційного навантаження на динаміку часових параметрів варіативності серцевого ритму у студентів із різним рівнем тривожності
}

\section{Карина Гочачко, Тетяна Качинська, Ольга Абрамчук, Наталія Кормош, Мар'яна Матолінець}

Східноєвропейський національний університет імені Лесі Українки, Луцьк, Україна

Адреса для листування: Kachynska.Tatiana @eenu.edu.ua

Отримано: 28.09.19; прийнято до друку: 20.11.19; опубліковано: 27.12.19

Резюме. У роботі виявлено вплив інформаційного навантаження на динаміку часових параметрів варіативності серцевого ритму у студентів із різним рівнем тривожності.

У дослідженні брали участь 28 студентів чоловічої і жіночої статі віком 18-20 років із різним рівнем особистісної тривожності (високий та середній). Запис варіативності серцевого ритму проводили на базі Східноєвропейського національного університету імені Лесі Українки. Експеримент проходив у 2 етапи: психологічний; запис ВСР. Досліджували часові показники ВСР. Запис ВСР проводили під час експериментальних ситуацій: стан спокою - контрольна проба (I проба), 3 інформаційним навантаженням (II проба) та з мотиваційним підкріпленням (III проба).

У студентів із високим рівнем тривожності під час інформаційного навантаження відбувалося зниження показників BCP - mRR, SDNN, RMSSD, pNN50, Mo, тоді як Amo, SI - зростали. У студентів, які мали середній рівень тривожності, показники mRR, SDNN, RMSSD, pNN50, Mo, навпаки, зростали, а Amo, SI знижувались. Це свідчить про переважання симпатичної ланки вегетативної нервової системи у досліджуваних обох експериментальних груп з більш вираженими змінами у студентів із високим рівнем тривожності. При цьому присутні великі енергозатрати регуляторних систем організму на підтримання гомеостазу. Зниження параметрів ВСР супроводжується централізацією регуляції ритму серця, що свідчить про зміщення вегетативного гомеостазу в бік переважання активності симпатичної нервової системи. Досліджувані з високою особистісною тривожністю характеризуються явищем компенсованого дистресу, що збільшує ризик захворювань серцево-судинної системи та зменшує рівень адаптації до всебічного потоку інформації.

Ключові слова: варіативність серцевого ритму, тривожність, мобілізуючий потенціал, відновний потенціал.

\section{Influence of information load on the dynamics of time parameters HRV in students with different levels of anxiety}

\section{Karina Gochachko, Tetiana Kachinska, Olha Abramchuk, Natalia Kormosh, Maryana Matolinets}

Lesia Ukrainka Eastern European National University, Lutsk, Ukraine

Correspondence: Kachynska.Tatiana@eenu.edu.ua 
Abstract. The aim of this study was to identify the effect of information load on the dynamics of time parameters HRV in students with different levels of anxiety.

The research was conducted on 28 males and females, 18-20 years old, divided into groups: I - high level of personal anxiety, II - medium level of personal anxiety. The experiment involved 2 stages: psychological; HRV record. The cardiointervalogram was registered with the usage of computer cardiographic complex «KardioLab». The recording of HRV was conducted in experimental situations: resting state - background (I) test, recording of HRV during information load - II test, recording of HRV during motivational reinforcement III test. Time indices of HRV were investigated.

Students with high level anxiety during information load the timing indexes of HRV decreased - mRR, SDNN, RMSSD, pNN50, Mo, whereas Amo, SI - increased. In students with moderate anxiety mRR, SDNN, RMSSD, pNN50, Mo - increased, and Amo, SI - decreased. This indicates the predominance of the sympathetic part of the autonomic nervous system in the studied both experimental groups with more pronounced changes in students with high levels of anxiety. At the same time there are large energy costs of the body's regulatory systems to maintain homeostasis. Reduction of HRV parameters is accompanied by centralization of regulation of heart rhythm, which indicates a shift of autonomic homeostasis toward the predominance of sympathetic nervous system activity. The subjects with high personal anxiety are characterized by the phenomenon of compensated distress, which increases the risk of diseases of the cardiovascular system and reduces the level of adaptation to the comprehensive flow of information.

Key words: heart rate variability, anxiety, mobilizing potential, restorative potential.

\section{ВСТУП}

Найважливіша особливість нашого часу стрімке зростання всіх видів інформації та іiі обсягу, що призводить до виникнення різних захворювань і патологічних станів [5]. Через величезні темпи зростання інформації розрив між ії кількістю і спроможністю сучасної людини іiі засвоїти постійно збільшується. Це призвело до формування такого психологічного стану як «інформаційна тривога». В освіті інформаційна революція призвела до значного збільшення обсягів навчального матеріалу, ускладнення мови підручників, стрімкого прискорення темпу навчання. Внаслідок цього інформаційний тиск на сучасного учня та студента посилюється 3 кожним днем, і як результат відбуваються певні зміни 3 боку регуляторних систем організму. А це так само призводить до розвитку різноманітних захворювань і патологій, насамперед з боку нервової, ендокринної та серцево-судинної систем.

Досліджуючи проблеми пристосування сучасної людини до життя, яке змінюється 3 надзвичайною, калейдоскопічною швидкістю, вчені дійшли висновку, що людство перебуває на межі масового адаптаційного зриву. Під впливом стресових факторів інформації, які постійно зростають у кількісному та якісному вимірах, відбувається надзбудження нервової системи людини, що $з$ часом призводить до іiі енергетичного виснаження. Величезні потоки інформації, які змушена «пропускати через себе» сучасна людина, 3 небувалою силою обрушилися на іiі органи чуття, спричинивши виникнення серйозної недуги «шоку майбутнього» - нової соціальної хвороби, причиною якої $\epsilon$ все більший розрив між швидкістю змін у навколишньому середовищі й обмеженою швидкістю людської реакції [10].

У цьому сенсі істотне місце належить питанням адаптації студентів, оскільки навчання у вищій школі $є$ складним і тривалим процесом, що вимагає витрат внутрішньої енергії, фізичних зусиль та емоційної стійкості [7]. Постійні зміни і реформи в системі вищої освіти, інтенсифікація навчання, збільшення потоку інформації пред'являють підвищені вимоги до функціональних можливостей студентів.

Спостерігається зростання необхідності переробки великих обсягів інформації за менший відрізок часу для іiї засвоєння. Через це особливої актуальності набувають дослідження індивідуальних особливостей i механізмів адаптації студентів до інформаційного навантаження. До того ж навчальна робота студентів має свою специфіку та особливості, пов'язані 3 характером занять, профілем навчального закладу та факультету. У зв'язку 3 цим важливого значення набуває питання про можливість специфічного впливу змісту освітньої програми на основні компоненти варіативності серцевого ритму (ВСР).

Для вивчення процесів адаптації до різного роду навантажень одним із найбільш ефективних методичних підходів $є$ математичний аналіз ритму серця, оскільки він дозволяє здійснити кількісно-якісну оцінку стану регуляторних систем організму, зокрема систем, що беруть участь у регуляції кровообігу [6; 8].

Отже, 3 вищесказаного випливає, що проблема інформаційного перенавантаження на сьогодні є дуже актуальною, не лише через те, що студентство проводить частину свого життя за навчанням, але й тому, що освітні установи 
мають неабиякий вплив на формування у молодих людей життєвих орієнтирів, а також цінності здоров'я та здорового способу життя.

Мета роботи - виявити вплив інформаційного навантаження на динаміку часових параметрів варіативності серцевого ритму у студентів із різним рівнем тривожності.

\section{МАТЕРІАЛИ Й МЕТОДИ ДОСЛІДЖЕНЬ}

У дослідженні варіабельності серцевого ритму брали участь 28 студентів чоловічої i жіночої статі віком 18-20 років із різним рівнем тривожності (високий та середній). Участь студентів у дослідженні передбачала їхню добровільну поінформовану згоду, а також попереднє ознайомлення 3 процедурою запису ВСР. Дослідження проводили 312.00 до 16.00 години в робочі дні тижня. За даними медичних карток студенти були здоровими.

Дослідження варіативності серцевого ритму проводили на базі Східноєвропейського національного університету імені Лесі Українки. Експеримент проходив у 2 етапи психологічний та запис ВСР.

Під час першого етапу, за допомогою опитувальника Спілбергера - Ханіна, було визначено рівень особистісної тривожності досліджуваних осіб [9]. Другий етап передбачав запис ВСР за допомогою комп'ютерного кардіографічного комплексу «Кардіолаб» (XАI Медика, м. Харків). Реєстрацію 5-хвилинного запису кардіоритмограми досліджуваного було проведено в лабораторії без сторонніх осіб, при температурі повітря $19-23^{\circ} \mathrm{C}$ в положенні сидячи (обстежуваний не розмовляв i не рухався). Запис ВСР проводили під час експериментальних ситуацій: стан спокою контрольна проба (I проба), 3 інформаційним навантаженням (II проба) та 3 мотиваційним підкріпленням (III проба). Для інформаційного навантаження було використано розв'язання арифметичних завдань, що полягало у множенні двозначних чисел. Ефективність виконання завдання визначали за кількістю правильно розв'язаних за 5 хв. завдань (точність) та загальною кількістю виконаних завдань (швидкість виконання). Між пробами досліджуваний відпочивав 8-10 хвилин. Безпосередньо перед початком запису ВСР студенти протягом 5-7 хвилин адаптовувалися до умов дослідження.

Механізми регуляції серцевої діяльності та стан вегетативної нервової системи аналізували за часовими (статичними та геометричними) показниками варіативності серцевого ритму:
mRR (мс) - середня тривалість інтервалів R-R; SDNN (мс) - стандартне відхилення (SD) величин нормальних інтервалів R-R (NN); RMSSD (мс) - квадратний корінь із середніх квадратів різниць величин послідовних пар інтервалів NN; pNN50, \% - відсоток послідовних інтервалів $\mathrm{NN}$, між якими відмінність перевищує 50 мс; Мо (мс) значення рівня функціонування серцевосудинної системи, яке трапляється найчастіше; Amo, \% - амплітуда моди; ИН(SI) - індекс напруження, що характеризує стан адаптаційно-пристосувальних можливостей організму та ступінь централізації управління серцевим ритмом [1]. Статистичну обробку проводили 3 використанням пакету програм «STATISTICA 6». Різницю між двома середніми величинами приймали за достовірну при значенні $\mathrm{t} \geq 2,0$ і $\mathrm{p} \leq 0,05$ [4].

\section{РЕЗУЛЬТАТИ}

Під час запису ВСР у досліджуваних засвідчено зміни значень часових показників до та після надання інформаційного навантаження, а також відмінності між показниками високого та середнього рівнів тривожності. Так, показник $\mathrm{mRR}$ під час першого дослідження $\mathrm{y}$ студентів із високим рівнем тривожності до інформаційного навантаження становив $683 \pm 24$ мс, в той час як 3 інформаційним навантаженням значення цього показника становило $678 \pm 17$ мс без мотивації та $677 \pm 15$ мс із мотивацією. У досліджуваних із середнім рівнем тривожності $\mathrm{mRR}$ у контролі становив $755 \pm 19$ мс, під час другої проби значення показника зменшилось до $706 \pm 17$ мс, а під час 3 проби до $697 \pm 19$ мс. Статистично достовірну різницю між значеннями $\mathrm{mRR}$ засвідчено $\mathrm{y}$ студентів 3 високим та середнім рівнем тривожності до надання інформаційного навантаження та в студентів із середнім рівнем тривожності 3 інформаційним навантаженням i мотиваційним підкріпленням (рис. 1.).

Отже, зменшення значення показника $\mathrm{mRR}$ свідчить про прискорення ЧСС, що так само може вказувати на збільшення регуляції серцевої діяльності симпатичним відділом ВНС під час надання інформаційного навантаження та мотивації незалежно від рівня тривожності. Показник SDNN у студентів обох груп дослідження має низхідну динаміку. Під час запису першої проби ВСР у студентів високого рівня тривожності значення показника становило 53,9 $\pm 5,4$ мс, під час II проби значення зменшилось до $51,6 \pm 4,3$ мс, а після 
Вплив інформачійного навантаження на динаміку часових параметрів варіативності сериевого ритму у студентів із різним рівнем тривожності

мотивації досліджуваних дані зросли до $53,6 \pm 5,3$ мс. У другої групи досліджуваних під час запису контрольної проби значення цього параметра становили $69 \pm 6,1$ мс, у II пробі дослідження показники зменшились до $62,3 \pm$ 7,3 мс, а після мотивації становили $62 \pm 5,4$ мс. Статистично достовірної різниці між значеннями SDNN не виявлено (рис. 1). Параметр варіативності серцевого ритму SDNN має тенденцію до зменшення і в такий спосіб відображає переважання симпатичного рівня регуляції вегетативної нервової системи.

Часовий показник RMSSD варіативності серцевого ритму у студентів 3 високим рівнем тривожності під час першого запису (контроль)

\section{I}

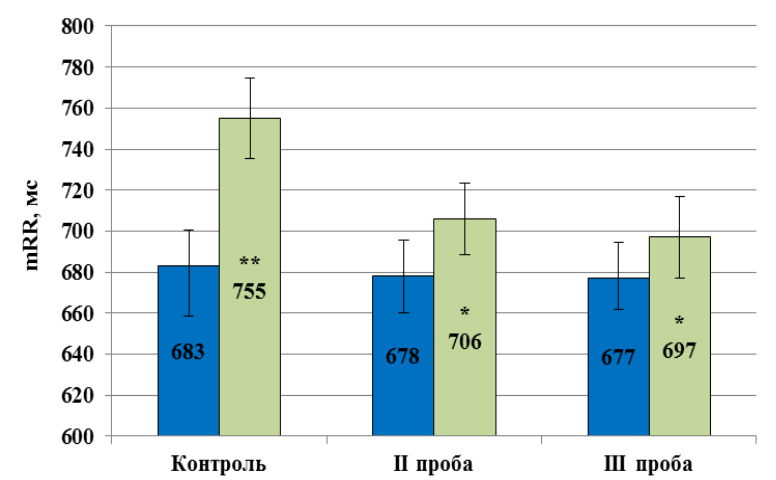

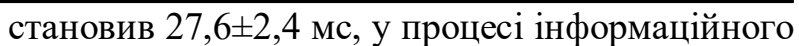
навантаження спостерігали його зменшення до $25,4 \pm 2,6$ мс, а під час запису III проби значення показника становило $26,4 \pm 2,4$ мс. В осіб, які мали середній рівень тривожності, цей показник також мав тенденцію до зниження. Так, під час запису I проби значення показника становило $43 \pm 5$ мс, під час II проби - $33 \pm 3,7$ мс, III проби - 33,3 $\pm 3,7$ мс. Отже, спостерігаємо зменшення значень показника RMSSD у студентів як $з$ високим, так і з середнім рівнем тривожності після надання інформаційного навантаження, та деяке його зростання під час мотивації. Статистично достовірну різницю між значеннями RMSSD засвідчено у студентів

II

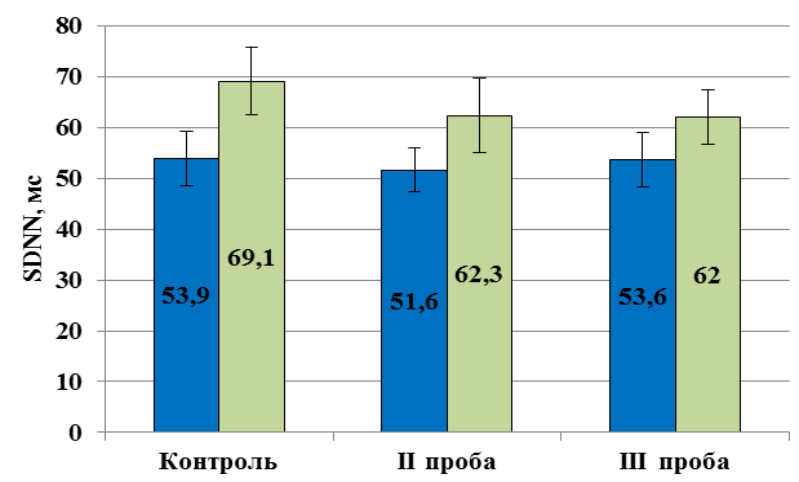

$\square$ середній рівень тривожності

Рис. 1. Показник mRR (I) ma SDNN (II) варіативності сериевого ритму у студентів із високим та середнім рівнем тривожності

Примітки. * - статистично достовірна різниия в межах групи порівняно з контролем $(p \leq 0,05)$; ** - міжгрупова статистично достовірна різниия ( $p \leq 0,05)$.

I

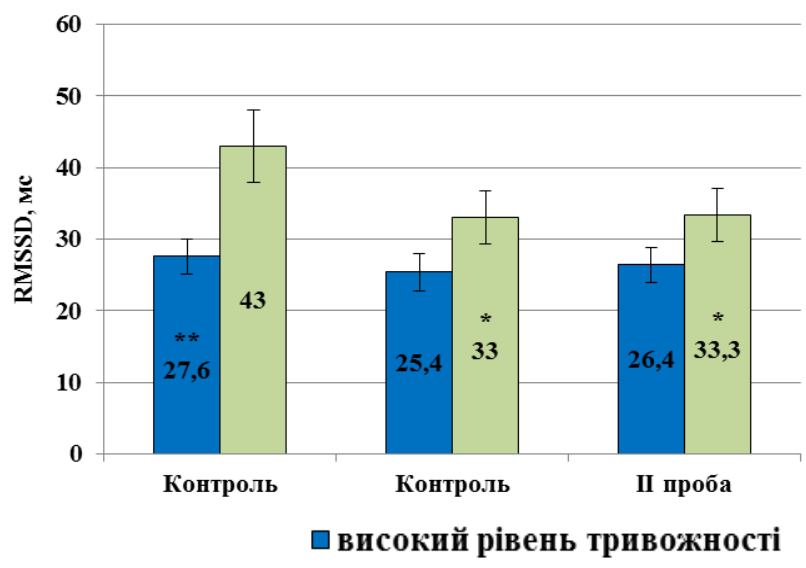

II

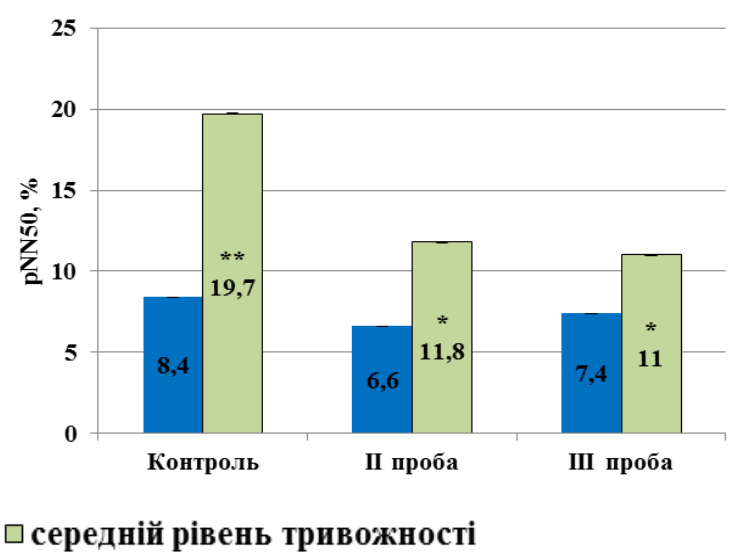

Рис. 2. Показник RMSSD (I) та pNN50 (II) варіативності сериевого ритму у студентів із високим та середнім рівнем тривожності

Примітки. * - статистично достовірна різниия в межах групи порівняно з контролем ( $p \leq$ $0,05) ; * *$ - міжгрупова статистично достовірна різниия $(p \leq 0,05)$. 
із високим та середнім рівнем тривожності під час запису I проби ВCP (контроль) та в студентів середнього рівня тривожності під час запису I, II та III проб відповідно (рис. 2).

Показник RMSSD відображає активність автономного контуру регуляції. Чим вище його значення, тим активніший вплив парасимпатичної регуляції. За результатами нашого дослідження під час запису ВСР у досліджуваних із високим та середнім рівнем тривожності спостерігається підвищення тонусу та активації симпатичної нервової системи на серцеву діяльність, що більш виражено в осіб із середнім рівнем тривожності.

Показник pNN50 у студентів із високим рівнем тривожності під час запису I проби ВСР становив $8,4 \pm 0,01 \%$, після надання інформаційного навантаження значення зменшилось до $6,6 \pm 0,01 \%$, а під час III проби знову зросло до $7,4 \pm 0,01 \%$. Показники досліджуваних середнього рівня тривожності мають більш виражену тенденцію до зменшення. Значення контрольної проби становило $19,7 \pm 0,03 \%, 3$ інформаційним навантаженням - $11,8 \pm 0,02 \%$, а 3 мотивацією $-11 \pm 0,02 \%$ (рис. 2).

За такою зміною значень pNN50 можна стверджувати про послаблення парасимпатичних впливів на ритм серця та відносне переважання симпатичної нервової системи в регуляції серцевої діяльності в досліджуваних обох груп. Проте більш виражений вплив спостерігається в осіб із середнім рівнем тривожності.

У студентів високого рівня тривожності під час запису I проби ВСР показник Мо становив

I

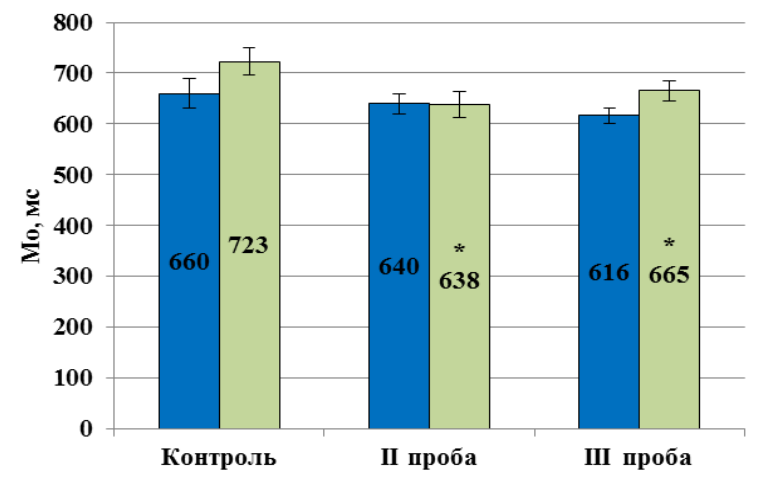

๑ високий рівень тривожності
$660 \pm 29$ мс, під час II проби значення параметра зменшилось до $640 \pm 20$ мс, а під час III проби становило $616 \pm 16$ мс. В осіб із середнім рівнем тривожності попередньо цей показник мав більше значення і під час запису контрольної проби становив $723 \pm 27$ мс. У процесі запису II проби значення показника зменшилось до $638 \pm 25$ мс, а в III пробі становило $665 \pm 19$ мс. Статистично достовірну різницю між значеннями Мо виявлено в групі із середнім рівнем тривожності: між значеннями контрольної проби та 3 інформаційним навантаженням i значеннями контрольної проби та з мотивацією (рис. 3).

Зниження значення показника Мо вказує на переважання впливу симпатичного відділу вегетативної нервової системи. За результатами кардіографічного дослідження було виявлено зменшення показника Мo, незалежно від експериментальної ситуації, що свідчить про вплив інформаційного навантаження та мотиваційного підкріплення на регуляцію роботи серця ВНС із послабленням парасимпатичного впливу. Чим нижчий показник Мо, тим більша частота серцевих скорочень відповідно. А отже, зі збільшенням інформаційного навантаження показник моди ВСР у студентів обох груп дослідження знижується, що свідчить про активацію симпатичного впливу на регуляцію роботи серця.

Часовий показник Amo варіабельності серцевого ритму у студентів із високим рівнем тривожності під час запису I проби ВСР становив $39,5 \pm 0,02 \%$, під час запису II проби спостерігали його зменшення до $37,8 \pm 0,02 \%$, а

II

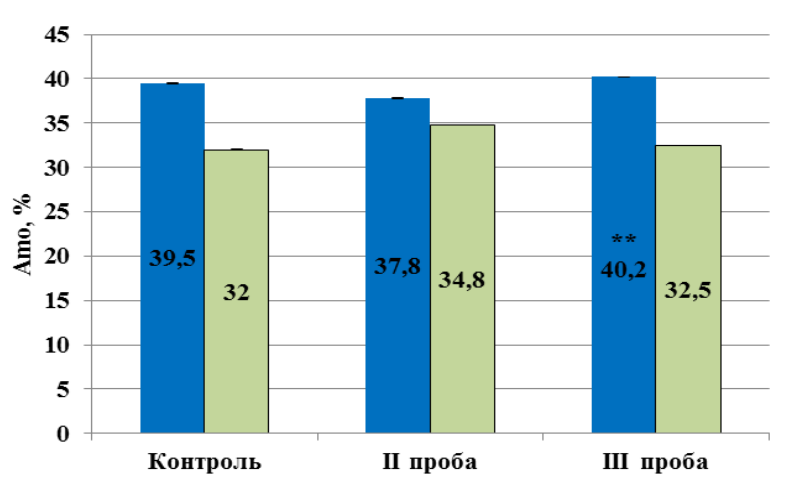

$\square$ середній рівень тривожності

Рис. 3. Показник Мо (I) та Ато (II) варіативності сериевого ритму студентів із високим та середнім рівнем тривожності

Примітки. * - статистично достовірна різниия в межах групи порівняно з контролем ( $p \leq$ $0,05) ; * *$ - міжсгрупова статистично достовірна різниия $(p \leq 0,05)$. 
Вплив інформачійного навантаження на динаміку часових параметрів варіативності сериевого ритму у студентів із різним рівнем тривожності

під час запису проби ВСР 3 мотиваційним підкріпленням значення параметра зросло до 40,2 $\pm 0,03 \%$. У досліджуваних, які мали середній рівень тривожності, під час контрольного запису значення показника становило $32 \pm 0,02 \%$, під час запису 3 інформаційним навантаженням показник збільшився до $34,8 \pm 0.01 \%$, а під час запису III проби значення параметра зменшилось до $32,5 \pm 0,01 \%$. Статистично достовірну різницю між значеннями Ато відзначено під час запису III проби порівняно з II у студентів високого та середнього рівня тривожності (рис. 3).

Показник Ато відображає ефект централізації управління ритмом серця. Підвищення цього показника вказує на збільшення активності симпатичної нервової системи та високу мобілізацію резервів органів кровоносної системи. Це також свідчить про підвищення адренергічних впливів на серцевий ритм у досліджуваних - після мотиваційного підкріплення в осіб 3 високим рівнем тривожності та після надання інформаційного навантаження у студентів із середнім рівнем тривожності. Натомість його зниження вказує на підвищення активності парасимпатичного відділу вегетативної нервової системи й відносно слабку централізацію управління серцевим ритмом, що спостерігається після надання інформаційного навантаження в осіб із високим рівнем тривожності та після мотивації у студентів середнього рівня тривожності.

Індекс напруження, або стрес-індекс (ИН(SI)), має як висхідну, так i низхідну динаміку. У студентів із високим рівнем тривожності під час запису контрольної проби ВСР значення показника становили $147,9 \pm 27$, під час II проби експерименту дані знизились до $141,9 \pm 19$, а після мотивації студентів різко підвищились до $172 \pm 39$. У студентів із середнім рівнем тривожності у першій експериментальній пробі значення показника становили $93 \pm 16$, під час запису II проби -

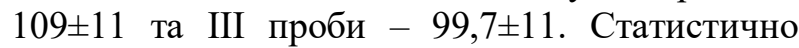
достовірної різниці між значеннями ИН(SI) не виявлено (рис. 4).

SI - стрес-індекс за Баєвським характеризує активність механізмів симпатичної регуляції та стан центрального контуру регуляції [2]. Чим він нижчий, тим менше напруження організму відповідно. Нами було відзначено загалом збільшення значень показника в процесі проведення експерименту. Враховуючи рівень тривожності, у студентів I групи під час надання мотивації спостерігаємо підвищення значень цього показника, що дає підставу говорити про зростання психоемоційної напруженості організму. В той час, як $\mathrm{y}$ студентів із середнім рівнем тривожності тенденція до підвищення показника $€$ менш вираженою, що відображає дещо більшу врівноваженість вегетативної нервової системи в управлінні серцевим ритмом.

\section{ОБГОВОРЕННЯ}

У студентів із високим рівнем тривожності після надання інформаційного навантаження відбувалося зниження показників BCP - mRR, SDNN, RMSSD, pNN50, Мо, тоді як Amo, SI зростали. У студентів, які мали середній рівень тривожності, показники mRR, SDNN, RMSSD, pNN50, Мо, навпаки, зростали, а Аmo, SI знижувались.

Це свідчить про переважання симпатичної ланки вегетативної нервової системи в досліджуваних обох експериментальних груп iз більш вираженими змінами у студентів

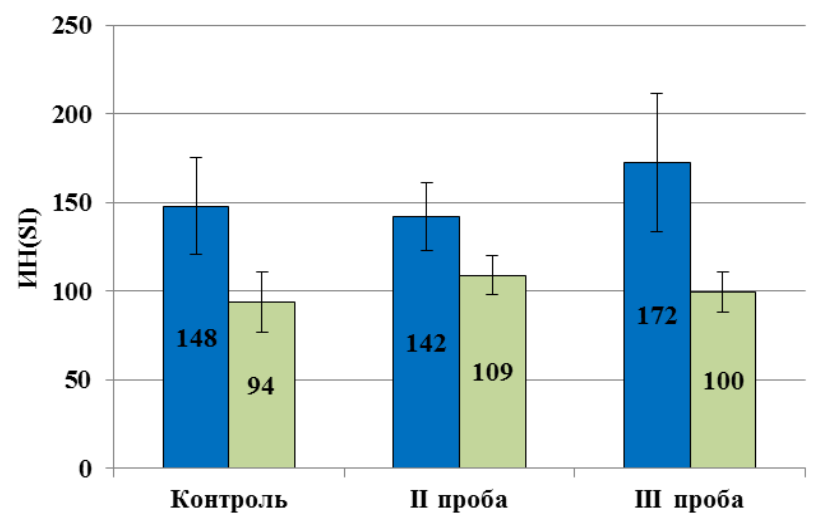

口 високий рівень тривожності $\square$ середній рівень тривожності

Рис. 4. Показник ИН(SI) варіативності сериевого ритму у студентів із різним рівнем тривожності

iз високим рівнем тривожності. При цьому присутні великі енергозатрати регуляторних систем організму на підтримання гомеостазу. Зниження параметрів ВСР супроводжується централізацією регуляції ритму серця, що свідчить про зміщення вегетативного гомеостазу в бік переважання активності симпатичної нервової системи. При такому типі регуляції організм працює в умовах стресу [3]. Зі збільшенням інформаційних навантажень ступінь симпатичних впливів на ритм серця збільшується, знижуються функціональні можливості серцево-судинної системи та функціональні резерви організму відповідно. 
Виявлено, що в студентів із високим рівнем тривожності спостерігаються високі значення індексу напруження Р. М. Баєвського, які зі свого боку вказують на зменшення адаптаційних можливостей, а разом 3 тим і на більшу напруженість організму та зниження функціональних резервів. В той час як у студентів із середнім рівнем тривожності ступінь функціональних резервів в організмі $\epsilon$ більшим.

\section{ВИСНОВКИ}

У студентів із середнім та високим рівнем особистісної тривожності під час інформаційного стресу та виконання завдання 3 мотиваційним підкріпленням виявлено збільшення значень показника SI, що свідчить про зростання напруженості організму. Проте досліджувані 3 високою особистісною тривожністю характеризуються явищем компенсованого дистресу, що збільшує ризик захворювань серцево-судинної системи та зменшує рівень адаптації до всебічного потоку інформації.

\section{ЛITЕРАТУРА}

1. Baevsky, R. M. Analysis of heart rate variability: history and philosophy, theory and practice. Clinical computer science and telemedicine, 2004, 1, 54-64.
2. Baevsky, R. M. Theoretical and applied aspects of assessing and predicting the functional state of an organism under the influence of factors of long space flight: Actual speech at a meeting of the Scientific Council of the SSC RF. IBMP RAS: Moscow, 2005, $12-13$.

3. Baevsky, R. M.; Ivanov, G. G. Heart rate variability: theoretical aspects and clinical applications. Ultrasd. and functional. Diagnostics, 2001, 3, 108-127.

4. Eliseeva, I. I. General theory of statistics. Finance and statistics: Moscow, 2004, 656.

5. Fedorov, V. N. Physiological mechanisms of the formation of adaptive heart rate reactions in adolescence. Bulletin of KarNU, 2009, 3, 5-6.

6. Goit, R. K.; Paudel, B. H.; Khadka, R.; Roy, R. K.; Shrewastwa, M. K. Mild-to-moderate intensity exercise improves cardiac autonomic drive in type 2 diabetes. J Diabetes Investig, 2014, 5(6), 722-727.

7. Isakov, I. A.; Lyashenko, V. P.; Petrov G. S. Vegetative manifestations of reactions of urgent adaptation of students to information load. Scientific Notes of Tavrida National University, 2013, 4, 46-59.

8. Nikishin, A. G.; Nurbaev, T. A.; Khasanov, M. S.; Abdullaeva. S. Y.; Yakubbekov, N. T. Possibility of the Heart Rate Variability Correction with a High Dose of Omega- 3-polyunsaturated Fatty Acids in Patients with Acute Myocardial Infarction and Concomitant Type 2 Diabetes Mellitus. International Journal of BioMedicine. 2014, 4(3), 138-142.

9. Pashukova, T. I. Practice Book on General Psychology. Znania: Kiev, 2000, 204.

10. Vigovska, O. Professionalism of a teacher as a guarantor of health protection. Director of the school, lyceum, gymnasium, 2005, 2, 48-50. 